\title{
The Influence of School Leadership and Committee Performance on Improving the Quality of Learning Islamic Education
}

\author{
Kamsia Nur'aini ${ }^{*}$, Ahmad Syahid ${ }^{2}$, and Rustina Rustina ${ }^{3}$ \\ ${ }^{1}$ Islamic Education Department, Postgraduate, Institut Agama Islam Negeri Palu \\ 2 Islamic Education Department, Postgraduate, Institut Agama Islam Negeri Palu \\ ${ }^{3}$ Islamic Education Department, Postgraduate, Institut Agama Islam Negeri Palu
}

ABSTRACT

This study aims to determine the effect of school committee performance on improving the quality of educational learning and principal leadership on Islamic learning. This study uses quantitative methods because the research data is in the form of numbers and the analysis uses statistics. The variables in this study are the contribution of the school committee's performance, the leadership of the school principal and the improvement of the quality of learning Islamic religious education. The data were processed using SPSS version 21. The results showed that there was a significant influence between the performance of the school committee and the improvement of the learning quality of Islamic religious education by $37.8 \%$ and the remaining $62.2 \%$ was influenced by other factors outside the research. This data shows that the higher the influence of the school committee's performance, the higher the increase in the quality of learning. In other words, the school committee is an institution that is located in each educational unit, and is an independent body that does not have a hierarchical relationship with government institutions that are in the middle between parents, students, teachers, and the local community. Furthermore, there is the influence of the principal's leadership on improving the quality of Islamic religious education learning by $66.4 \%$ and the difference of $33.6 \%$ is influenced by other factors outside the research. This data shows that the higher the influence of the principal's leadership, the higher the increase in the quality of learning.

\section{ARTICLE \\ INFORMATION}

\section{Keywords:}

School Committee Performance, Principal Leadership, The quality of Islamic Religious Education 


\section{Introduction}

The principal is one of the human resources who plays a very important role in regulating and controlling all related resources in the field of education units, especially in schools. The principal is an important figure in the school because the principal is responsible for the progress and decline of a school as well as the pros and cons. The leadership of the principal in the education unit in schools is the driving force for all school resources which are expected to be able to motivate teachers to be more effective, build and foster good relations between school environments in order to create an atmosphere that is conducive, exciting, productive and together to be able to implement planning, implementing and evaluating various types of policies and changes that have been carried out effectively and efficiently so that all are directed to produce quality products or graduates with superior competencies.

Mulyono stated that the principal must be responsible for the running of school institutions and activities in the school. The principal has main activities that must be carried out, namely planning, organizing, holding staff, directing/targeting orientation, coordinating, monitoring and assessing/evaluating. ${ }^{1,}$ The school

1Mulyono. Manajemen Administrasi dan Organisasi Pendidikan. Jogjakarta: Ar-Ruzz Media, 2009), 147

${ }^{2}$ Nurdin, N., Stockdale, R., \& Scheepers, H. (2014a). Coordination and Cooperation in EGovernment: An Indonesian Local EGovernment Case The Electronic Journal of Information Systems in developing Countries, 61(3), 1-21. principal has a role in conducting coaching teaching programs. Teaching coaching is an effort to improve teaching programs to be understood by every principal.

Then according to Stoner and Freeman which has been translated by Ambar Teguh Sulistiyani Rosidah argues that: Management is the process of planning, organizing, leading, and controlling the efforts of organizational members and the process of using all other organizational resources to achieve the stated organizational goals. ${ }^{3,4}$

According to Mulyasa, the school committee is an independent body that accommodates community participation in the context of improving the quality, equity and efficiency of education management in schools. The school committee is located in the school, and each school can have a school committee or join other schools to establish a school committee. Improving the quality of education is one of the efforts of the government, community and school committee which is the representative of the parents of students. In improving the quality of human resources, education is one of the aspects of national development which is very important for realizing reliable, professional and

3 Rosidah, Sulistiyani, Teguh, Ambar Manajemen.Sumber Daya Manusia: Konsep,

Teori dan Pengmebangan dalam Konteks Organisasi Publik, (Yogyakarta, Graha Ilmu, 2009), 8

4 Nurdin, N. (2018). Institutional Arrangements in E-Government Implementation and Use: A Case Study From Indonesian Local Government. International Journal of Electronic Government Research (IJEGR), 14(2), 44-63. https://doi.org/10.4018/ijegr.2018040104

e-ISSN: 2715-4572 p-ISSN: 2716-1439 
highly competitive citizens. Juridically reflected in article 31 of the 1945 Constitution which reads: Every citizen of the state has the right to receive instruction (article 1); The government strives and implements a traditional teaching system which is regulated in law (Nana Karyana in Ojo Karman). ${ }^{5}$

The performance of the School Committee at 8 Balaesang Elementary School in terms of monitoring the implementation of school programs, which consists of monitoring school organizations, monitoring school program scheduling, monitoring budget allocations for implementing school programs, monitoring school program implementing resources, monitoring the participation of education stakeholders in the implementation of school programs, also implemented through reports submitted by the Principal. In this case the School Committee provides input or suggestions about the teaching and learning process to schools, for example by suggesting always giving homework to students so that students continue to study at home every day.

The committee monitors through reports submitted by the principal. The school committee always pays attention to the results of school final exams. If the results are not good, the committee always looks for the cause. The principal of 8 Balaesang Elementary School has a

5 Ojo Karman. kontribusi kinerja komite sekolah dan kepemimpinan kepala sekolah terhadap peningkatan mutu pembelajaran di sekolah.

https://media.neliti.com/media/public ations/75053-ID-kontribusi-kinerja-komitesekolah-dan-ke.pdf, diakses tanggal 10 pebruari 2019 harmonious relationship with the school committee. This relationship can be seen from the meeting activities and also the meetings held by the school principal and the school committee. Meetings with the school committee are held once a month.

School committees with schools and School committees with Education Boards. As a liaison, the 8 Balaesang Elementary School Committee maintains good relations with all parties, making it easier for school activities and problem solving. But unfortunately, until now the 8 Balaesang Elementary School committee has not been able to establish a relationship with the Education Board. Regarding the aspirations and policy proposals for education programs to schools, there is a lack of communication and cooperation with parents in dealing with problems faced by students. PAI teaching and learning activities are often concentrated in the classroom and are reluctant to carry out practical and research activities outside the classroom. The use of teaching media both by teachers and students is less creative, varied and fun.

Rivai \& Murni argues that there are three factors that cause the quality of education to not increase equally as follows: First, policies in the implementation of national education use the education production function approach or input-output analysis which is not implemented consequently; Second, the implementation of national education is carried out in a bureaucratic-centralized manner so that placing schools as education providers is highly dependent on bureaucratic 
decisions which have a very long path and sometimes the policies issued are not in accordance with local school conditions; Third, the role of school residents, especially teachers and the participation of the community, especially parents, in the delivery of education has been minimal. 6

Islamic education teaching and learning activities tend to be normative, linear, without an illustration of the socio-cultural context in which the students' environment is located, or can be related to the times that are very rapidly changing. It can be seen that problems in the learning process arise from various causes. Of course this problem becomes a job for educational practitioners and academics in initiating solutions to learning problems, especially in improving the quality of Islamic Education learning. The quality of Islamic Education learning which if implemented properly will produce a learning process that is able to bring students to understand and think critically and have noble morals.

The quality of the learning process developed by the teacher is also largely determined by the professional level of the teacher in carrying out the learning process in the classroom. The learning process that occurs in the classroom is carried out in accordance with the contribution of the school committee's performance, ${ }^{7}$ because its

6 Rivai \& Murni, Education Manajemen (Analisis Teori dan Praktik). (Jakarta, Rajawali Pers Divisi Buku Perguruan Tinggi PT. Raja Grafindo Persada, 2010), 615.

${ }^{7}$ Evita, E., Syahid, A., \& Nurdin, N. (2019). Understanding Students' Learning Outcomes Differences Through the Application of the contribution plays an important role for the progress of education in schools. However, in fact the teacher's ability in managing learning is not evenly distributed according to the educational background of the teacher and their motivation and love for their profession. There are teachers who carry out the management of learning carried out seriously through careful planning, by utilizing all available resources, and paying attention to the level of intellectual development and the development of children's learning psychology.

The Leadership of the Principal in Improving the Quality of Islamic education at 8 Balaesang Elementary School requires a contribution to the performance of the school committee and the Board of Education. As a liaison, the 8 Balaesang Elementary School Committee maintains good relationships with all parties, making it easier for school activities and problem solving. But unfortunately until now the 8 Balaesang Elementary School Committee has not been able to establish a relationship with the Board of Education.

Learning Islamic religion which is only in the form of advice, orders, prohibitions and memorization cannot shape the morals of students, but it needs examples and direct training so that good character can blend with

\footnotetext{
Market Place Activity Type of Cooperative Learning Model and the Application of Conventional Learning Models International Journal of Contemporary Islamic Education, 1(1), 6785.
} 
students. ${ }^{8}$ Islamic holidays and Islamic holidays are good opportunities to educate the religious feelings in the hearts of students. Learning can be defined as an activity designed to help someone learn a new ability or value.

In learning Islamic religious education, there are basic principles that must be considered. Among them is that the religion of Islam consists of a) faith, belief, faith, b) knowledge, c) behavior, morals. ${ }^{9}$ Therefore, the Islamic religious learning plan must include all three. Likewise, teachers who teach according to plan must be able to expand the material presented because this is useful for fostering a sense of religion and awakening enthusiasm in the hearts of students.

Regarding the aspirations and policy proposals for education programs to schools, there is a lack of communication and cooperation with parents in dealing with problems faced by students. Islamic education teaching and learning activities are often concentrated in the classroom and reluctant to do practical and research activities outside the classroom. The use of teaching media both by teachers and students is less creative, varied and fun. In this regard, in order to improve the quality of Islamic education at 8 Balaesang Elementary School effectively and efficiently, it is necessary to be supported by quality human resources as well. One of the components of

\footnotetext{
${ }^{8}$ Rusli, R. (2014c). Teaching Usul al-Fiqh: A Multicultural Education Model. Al-Tahrir: Jurnal Pemikiran Islam, 14(2), 447-464.

9 Mahmud Yunus, Metodik khusus Pendidikan Agama, ( Jakarta:Hidakarya Agung, 1999), 17
}

education that has the most role in improving the quality of education is the principal as the education leader (Mulyasa). ${ }^{10}$ Therefore, the strong leadership of the principal is one of the strategies to improve the quality of education at Balaisang Elementary School.

\section{Literature Review}

\subsection{Definition of School Committee Performance}

The formation of the school committee adheres to the principles of transparency, accountability and democracy. The school committee is expected to become a school partner who can accommodate and channel community aspirations and initiatives in creating operational policies in school education programs. The duties and functions of the school committee include encouraging the growth of public attention and commitment to quality education, encouraging parents and the community to participate in education in order to support the improvement of the quality and equity of education, and mobilizing the community in the framework of financing education in educational units. (SBM Guidelines; Directorate General of Management of Primary and Secondary Education; 2006). ${ }^{11}$

Along with the dynamics in the world of education, Law Number 20 of

10 Mulyasa, E. Menjadi Kepala Sekolah Profesional. Bandung: PT Remaja Rosdakarya. TARBAWY, Vol. 3, Nomor 1, (2016) | 76

11 Direktorat Jendral Manajemen Pendidikan Dasar dan Menengah; 2006. Panduan MBS 
2003 concerning the National Education System was born. The existence of the Education Board and School/Madrasah Committee as a form of community participation in the world of education is reaffirmed in article 56 paragraphs 1-4. Article 56 paragraph (1): The community plays a role in improving the quality of education services which includes planning, monitoring and evaluating educational programs through the education council and school/madrasah committee. ${ }^{12}$ Article 56 paragraph (2): The Education Council as an independent institution is formed and plays a role in improving the quality of education services by providing consideration, direction and support for personnel, facilities and infrastructure, as well as educational supervision at the National, Provincial and Regency/City levels that have no relationship. hierarchical. Article 56 paragraph (3): School/madrasah committees, as independent institutions, are formed and play a role in improving the quality of services by providing consideration, direction and support for personnel, facilities and infrastructure, as well as education supervision at the education unit level. Article 56 paragraph (4): Provisions regarding the formation of the Education Council and School/Madrasah Committee as referred to in paragraph (1), paragraph (2), and paragraph (3) shall be further regulated by Government Regulation. To fulfill the mandate of Law Number 20 of 2003 Article 56 paragraph (4), on

12 Undang-undang Republik Indonesia Nomor 20 Tahun 2003 tentang Sistem Pendidkan Nasional
January 28, 2010 the government issued Government Regulation Number 17 of 2010 concerning Management and Implementation of Education. ${ }^{13}$ Subsequently, on September 28, 2010, Government Regulation Number 66 of 2010 was issued which was an improvement to Government Regulation Number 17 of 2010. This Government Regulation provides a detailed explanation of various aspects related to the Education Board and school committee, including existence, operation, and legality.

Masaong and Ansar argued that the School committee is an institution that is located in each educational unit, and is an independent body that does not have a hierarchical relationship with government institutions that are in the middle between parents, students, teachers, local communities, and private sector. Which is formed and plays a role in improving the quality of services by providing consideration, direction and support for personnel, infrastructure, as well as educational supervision at the educational unit level. ${ }^{14}$

In line with Haryanto's opinion, the management and membership of the School Committee must reflect the parents of students and community leaders. The management and

13 Peraturan Pemerintah Republik Indonesia Nomor 66 Tahun 2010 Tentang Perubahan Atas Peraturan Pemerintah Nomor 17 Tahun 2010 Tentang Pengelolaan Dan Penyelenggaraan https://uk.staff.ugm.ac.id/atur/PP66-2010.pdf

14 Masaong dan Ansar. Manajemen Berbasis Sekolah. (Teori, Model, dan Implementasi di Sekolah Dasar. Gorontalo: Nurul Djanah, 2007), 165

e-ISSN: 2715-4572 p-ISSN: 2716-1439 
membership of the School Committee includes: (1) representatives of parents of students, (2) community leaders such as hamlet heads, scholars, cultural observers, and so on, (3) community members such as NGOs that care about education, (4) local government officials, (5) the business world and the industrial world, (6) education experts, (7) professional educational staff organizations such as Indonesian Republic Teachers Association, (8) student representatives, and/or alumni. ${ }^{15}$

According to Amarin, Sunandar, and Noor Miyono, the role of the school committee is seen from the existence of the Parents and Teachers Association which is formed in each class with a program of regular parent-student meetings and social activities. The school committee also plays an active role as a verifier of the accountability of school programs, School Budget Activity Plans and school financial reports. However, the school committee does not have a special committee work program in a year, so the committee works only from the school encouragement and routine programs of previous years at school. 16

Myers and Stonehill (in Umaedi, Hadianto, and Siswantari) have the view that School Based Management is a strategy to improve the quality of

${ }^{15}$ Haryanto. Komite Sekolah (Sejarah dan Prospeknya di Masa Depan). Yogyakarta: Hikayat Publishing, 2008), 96

16 Amarin, Sunandar, dan Noor Miyono Https:/ /Www.Researchgate.Net/Publication/3 21976513_Peran_Komite_Sekolah_Dalam_Manaj emen_Berbasis_Sekolah_Di_SD_Islam_Terpadu_ Buah_Hati_Kabupaten_Pemalang). education through the transfer of decision-making authority from the central government to the regions and to individual schools so that school principals, teachers, students, and parents of students have more control over the educational process, and also have the responsibility to make decisions regarding financing, personnel, and the school curriculum. Community participation in school administration has been regulated in an institution. ${ }^{17}$ The School Committee is expected to become a school partner who can accommodate and channel community aspirations and initiatives in creating operational policies and educational programs in schools.

The figure of a quality teacher can be seen from how optimally the teacher is able to facilitate the student learning process. Every teacher or educator has a responsibility for the success of student learning. Learning can only occur if the students themselves are motivated to learn. This motivation plays a very important role in learning activities, because it is an impetus or force that moves someone to do something. Then the teacher gradually understands the benefits of learning as a commendable life value, so that students learn because they are based on an understanding of higher values for the students' own lives. Although this process is not easy, the teacher must still try to instill a positive attitude in learning, because this is a very important part of the learning process to be able to learn well.

17 Umaedi, Hadiyanto dan Siswantari, Manajemen Berbasis Sekolah. (Jakarta: Universitas Terbuka, 2009), 4.3

e-ISSN: 2715-4572 p-ISSN: 2716-1439 


\subsection{Position and Nature of the School Committee}

The School Committee is located in an educational unit both schools and outside schools. Educational units with various levels, types and pathways of education have very diverse locations. There are single schools and there are schools in one complex. There are public schools and private schools run by educational organizations.

The School Committee is an independent body, has no hierarchical relationship with schools or other educational institutions. School committees and schools have their own independence, but remain partners who must work together in line with the concept of school-based management.

According to Tilaar, the implementation of education must involve the community because the community is the first and foremost stakeholder of the education process. This means that the educational process, educational objectives, and educational facilities, including the quality of education, are the responsibility of the local community. School is a system in which all resources are transformed with one mouth, namely the realization of education and learning services, along with the dynamics in the world of education. The existence of education boards and school/madrasah committees as a form of community participation in the world of education. ${ }^{18}$

The presence of the school committee has shown its role as a school

18 Tilaar, H.A.R. Membenahi Pendidikan Nasional. (Jakarta: PT.Rineka Cipta, 2002), 27 partner, especially for school principals and teachers in designing and implementing educational programs, both physical and non-physical development programs such as classroom learning programs. However, in its progress, the school committee has not fully implemented its role and function as a school partner organization in assisting educational programs as planned. The above is in line with the reality put forward by the Director General of Education and Secondary Education in his remarks. The School Committee Empowerment Module stated that: Qualitatively, the existence of education boards and school committees has not been able to fully promote the quality of education services and this is of course caused by several factors. one of which is the lack of communication between education providers and stakeholders, in this case the community, which results in a lack of understanding of the importance of the role of the school committee.

\subsection{The Role of the School Committee}

The existence of the School Committee must be based on the foundation of community participation in improving the quality of services and educational outcomes in schools. Therefore, the formation must pay attention to the division of roles according to existing positions.

Mediator between the government (executive) and the community in the education unit (Minister of Education Decree No.044 /U/2002).

The role of the committee as a mediator so far has been in the form of a liaison between the principal and e-ISSN: 2715-4572 p-ISSN: 2716-1439 
the community, the principal and the education board and the principal and the school itself, in this case teachers, staff employees and students, besides that the committee also participates in making policy proposals and several programs education to schools.

In elaborating the operational activities of the role of the School Committee as the advisor, carrying out various activities such as:

Collecting data on the socio-economic conditions of students' families and educational resources in the community.

Provide input and consideration to the principal in the preparation of the Vision, Mission, Goals, Policies and School activities.

Analyze the results of data collection as material for providing input, considerations and recommendations of the principal.

Deliver written input, considerations and recommendations to the school with a copy to the Education Office and the Education Council.

Give consideration to schools in the context of developing a local content curriculum and enhancing a fun learning and teaching process.

Verifying the School Revenue and Expenditure Budget Plan submitted by the School Principal, endorsing the School Income and Expenditure Budget Plan after the verification process in the School Committee plenary meeting.

\subsection{Principal Leadership}

Mulyasa defines "Leadership is the art of persuading subordinates to be willing to do tasks with confidence and enthusiasm. ${ }^{19}$ Miftah Toha said that leadership is a relationship between a person and another, a leader is able to influence others to be willing to work together in related tasks to achieve the desired goals. ${ }^{20},{ }^{21}$ Reksoprodjo Handoko said that "Leadership is a relationship between a person and another, a leader is able to influence others to be willing to work together in related tasks to achieve the desired goals. ${ }^{22}$ Abi Sujak argues that leadership is a pattern of relationships between individuals who use authority and influence on another person or group of people in order to form cooperation to complete a task. ${ }^{23}$ According to Miftah Thoha, there are three factors that interact to determine leadership effectiveness, namely:

First, leader behavior, namely, leadership effectiveness is strongly influenced by one's leadership style. Second, subordinates, namely, leadership effectiveness is influenced by the level of acceptance and support of

19 Mulyasa E., Menjadi Kepala Sekolah Profesional, (Bandung : PT. Remaja, 2001), h. 17

20 Miftah Thoha, Kepemimpinan Dalam Manajemen Suatu Pendekatan Prilaku, (Jakarta : PT. Grafindo Persada, 1999), h. 89

${ }^{21}$ Nurdin, N., Stockdale, R., \& Scheepers, H. (2014b, 6-9 Jan. 2014). The Role of Social Actors in the Sustainability of E-Government Implementation and Use: Experience from Indonesian Regencies. System Sciences (HICSS), 2014 47th Hawaii International Conference on System Science

22 Reksoprodjo Handoko, Organisasi Perusahaan Teori Struktur dan Perilaku, (Yogyakarta : BPFE, 1994), h. 66

23 Abi Sujak, Kepemimpinan, Manajer (Eksistensinya dalam Prilaku Organisasi), (Jakarta : Rajawali Pers, 2009), h. 9

e-ISSN: 2715-4572 p-ISSN: 2716-1439 
subordinates. Subordinates will support a leader as long as they see the leader's actions as beneficial and increase their satisfaction. Third, the situation, namely, the situation in the leadership style: the relationship between the leader of the members, the level of the task structure and the position of power of the leader through formal authority. ${ }^{24}$

Principal leadership is essentially a principal who understands and masters effective managerial and leadership skills. The detailed aspects and indicators are as follows:

According to Wahjosumidjo, the principal is a functional teacher who is given the task of leading a school where a teaching and learning process is held or a place where there is interaction between the teacher who gives lessons and students who receive lessons. ${ }^{25}$ In English, leadership is often called leader from the root word to lead and the activity is called leadership. In the verb to lead is contained in several closely related meanings, namely, moving faster, walking forward, taking the first step, doing first, pioneering, directing the thoughts or opinions of others, guiding, guiding others moving earlier, go ahead, take the first step, act first, spearhead an action, direct thoughts or opinions, guide and move others through their influence. ${ }^{26}$ Meanwhile, according to the term leadership is the process of influencing individual or group activities to achieve certain goals in predetermined situations. In

24 Miftah Thoha, Op.Cit, h. 92

25 Wahjosumidjo, Op.Cit, h. 83

26 Imam Suprayogo, Revormulasi Visi

Pendidikan Islam, (Malang: Stain Press, cet. I, 1999), 161 influencing their activities, individual leaders use power, authority, influence, characteristics and characteristics, and the goal is to increase the productivity and morale of the group. ${ }^{27}$ In Islam the term leadership is often identified with the term khilafah and the person is called kholifah and Ulil Amri whose person is called Amir (the holder of power). ${ }^{28}$

According to Rivai, the definition of leadership is a process for influencing others to understand and agree with what is needed and how work is done effectively, as well as a process to facilitate individual and collective efforts to achieve goals. ${ }^{29}$ Robbins explains that leadership is the ability to influence a group for the achievement of organizational goals. ${ }^{30}$ Meanwhile, the definition of leadership according to Hersey \& Blanchard in Monica, is the action of a leader to influence others in achieving a goal in accordance with the organizational situation, which includes four things, namely: conveying or telling, selling, by participating or participating, and delegating. ${ }^{31}$

J. Reberu in the basics of leadership provides a definition of leadership. Leadership is the ability to move a group of people towards a common goal

27 Ibid, 161

28 Ibid, 162

29 Rivai Veitzai, Manajemen Sumber Daya Manusia untuk Perusahaan, (Edisi ke-6, PT Raja Gravindo Persada, 2014), 2

30 Robbins, Stephen P., Perilaku Organisasi: Konsep, Kontroversi dan Aplikasi, (Vol. 1. Jakarta: Prenhallindo, 1996), 39

31 Monica, E.L. Kepemimpinan dan Manajemen Keperawatan : Pendekatan berdasarkan pengalaman. (Terjemahan. EGC. Jakarta, 1998), 73

e-ISSN: 2715-4572 p-ISSN: 2716-1439 
while using the physical and spiritual forces that exist in the group. He further explained that leadership is a dynamic element that is able to study the past, study the present and highlight the future, to then have the courage to make decisions as outlined in the actions. , inviting, guiding, moving, and if necessary forcing others to receive influence to then do something that can help achieve something goals and objectives. $^{32}$

Figure 1. Theoretical Framework

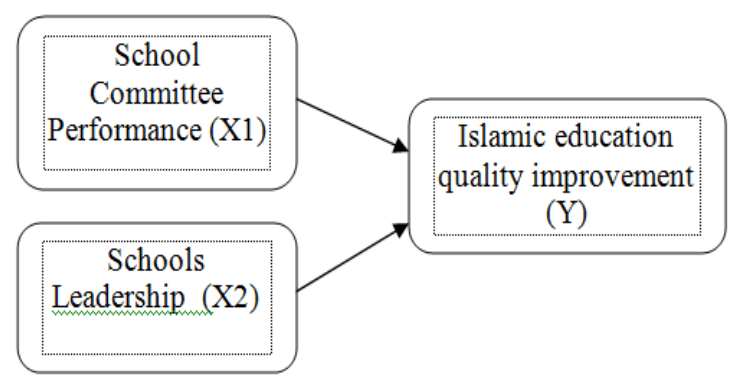

\section{Methodology}

This study uses a quantitative approach with survey techniques. The research object was the state elementary school 8 Balaesang Donggala. Researchers used purposive sampling sampling technique. This technique was chosen with the aim that the sample taken could represent the desired population characteristics. The sample in this study were 50 students' parents

The calculation of data analysis in this study is quantitative, with descriptive statistical analysis and inferential statistics using SPSS 21 and

32 Dirawat dkk, Pengantar Kepemimpinan Pendidikan, (Surabaya: Usaha Nasional, 1983), 23
Microsoft Excel 2007 programs. ${ }^{33}, 34$ Descriptive statistics aim to obtain an overview of respondents, while inferential statistics are used for hypothesis testing. Hypothesis analysis using software, namely SPSS 21 . The data obtained was tested with a simple linear regression analysis model to test the effect of the independent and dependent variables.

\section{Results}

\section{a. Correlation Test}

Pearson Product Moment correlation test is one of several types of correlation test used to determine the degree of closeness of the relationship between 2 variables on an interval or ratio scale. With this test, a correlation coefficient value will be obtained between $-1,0$ and 1 . A value of -1 means that there is a perfect negative correlation, 0 means there is no correlation and a value of 1 means that there is a perfect positive correlation. Thus, the closer to number 1 , the greater the correlation between these variables. Conversely, the closer it is, the smaller the correlation between the two variables.

${ }^{33}$ Nurdin, N., Pettalongi, S. S., \& Ahsan, M. N. (2019). Implementation of Teaching Quality Assessment System Using Android. 2019 5th International Conference on Science and Technology (ICST

34 Nurdin, N., Pettalongi, S. S., \& Mangasing, M. (2019). Understanding Digital Skill Use from The Technology Continuance Theory (TCT). 2019 6th International Conference on Information Technology, Computer and Electrical Engineering (ICITACEE), 
Correlation is said to be significant if the significance value is smaller than 0.05 . If the significance value is greater than 0.05 , it means that the correlation is not significant.

Korelasi Kinerja Komite Sekolah dengan Mutu Pembelajaran PAI dapat dilihat pada tabel 1 berikut.

The correlation of the school committee's performance with the quality of Islamic education learning can be seen in table 1 below.

Table 1. Correlation Between Variable

\section{Correlations}

\begin{tabular}{|c|c|c|c|}
\hline & & $\begin{array}{l}\text { School } \\
\text { Committee } \\
\text { Performan } \\
\text { ace }\end{array}$ & $\begin{array}{l}\text { Islamic } \\
\text { Education } \\
\text { Teaching } \\
\text { Quality }\end{array}$ \\
\hline \multirow{3}{*}{$\begin{array}{l}\text { School } \\
\text { Committee } \\
\text { Performan } \\
\text { ace }\end{array}$} & $\begin{array}{l}\text { Pearson } \\
\text { Correlation }\end{array}$ & 1 & $.924^{88}$ \\
\hline & $\begin{array}{l}\text { Sig. } \\
\text { tailed) }\end{array}$ & & .000 \\
\hline & $\mathrm{N}$ & 50 & 50 \\
\hline \multirow{3}{*}{$\begin{array}{l}\text { Islamic } \\
\text { Education } \\
\text { Teaching } \\
\text { Quality }\end{array}$} & $\begin{array}{l}\text { Pearson } \\
\text { Correlation }\end{array}$ & $.924^{88}$ & 1 \\
\hline & $\begin{array}{l}\text { Sig. } \\
\text { tailed })\end{array}$ & .000 & \\
\hline & $\mathrm{N}$ & 50 & 50 \\
\hline
\end{tabular}

**. Correlation is significant at the 0.01 level (2tailed).

In the table above, it can be seen that the correlation between the School Committee's Performance and the Quality of Islamic Education Learning is 0.924 with a significance of 0.000 . The Product Moment correlation coefficient of 0.924 based on the above criteria shows a very strong relationship between the School Committee Performance variable and the Quality of Islamic Education Learning. The numbers are close to 1 . The significance value in the table is above 0.000> 0.05 . This shows that the correlation of the school committee performance variable with the quality of Islamic education learning is very significant. Thus, it can be concluded that there is a significant correlation between the School Committee Performance variable and the Quality of Islamic Education Learning

Korelasi Kepemimpinan Kepala Sekolah dengan Mutu Pembelajaran PAI dapat dilihat pada tabel 2 berikut.

The correlation of the Principal's Leadership with the Quality of Islamic Education Learning can be seen in table 2 below.

Table 2. Correlation Between variables

\begin{tabular}{|c|c|c|c|}
\hline \multicolumn{4}{|c|}{ Correlations } \\
\hline & & $\begin{array}{l}\text { Schools } \\
\text { Leadership }\end{array}$ & $\begin{array}{l}\text { Islamic } \\
\text { Education } \\
\text { Teaching } \\
\text { Quality }\end{array}$ \\
\hline \multirow[t]{3}{*}{$\begin{array}{l}\text { Schools } \\
\text { Leadership }\end{array}$} & $\begin{array}{l}\text { Pearson } \\
\text { Correlation }\end{array}$ & 1 & $.955^{88}$ \\
\hline & $\begin{array}{l}\text { Sig. } \\
\text { tailed) }\end{array}$ & & .000 \\
\hline & $\mathrm{N}$ & 50 & 50 \\
\hline \multirow{3}{*}{$\begin{array}{l}\text { Islamic } \\
\text { Education } \\
\text { Teaching } \\
\text { Quality }\end{array}$} & $\begin{array}{l}\text { Pearson } \\
\text { Correlation }\end{array}$ & $955^{88}$ & 1 \\
\hline & $\begin{array}{l}\text { Sig. } \\
\text { tailed) }\end{array}$ & .000 & \\
\hline & $\mathrm{N}$ & 50 & 50 \\
\hline
\end{tabular}
seen that the correlation of the Principal's Leadership with the Quality of Islamic Education Learning is 0.955 with a significance of 0.000 . The Product Moment correlation coefficient of 0.955 based on the above criteria shows a very strong relationship between the Principal Leadership variable and the 
Quality of Islamic Education Learning. The numbers are close to 1 . The significance value in the table is above $0.000>0.05$. This shows that the correlation of the Principal Leadership variable with the Quality of Islamic Education Learning is very significant. Thus, it can be concluded that there is a significant correlation between the Principal Leadership variable and the Quality of Islamic Education Learning.

\section{b. Multiple Regression Test}

Multiple regression is a regression or predictive model that involves more than one independent variable or predictor. The term multiple regression can also be referred to as multiple regression. The word multiple means plural or more than one variable.

Table 3. Variables Entered/Removed

\begin{tabular}{|l|l|l|l|}
\hline \multicolumn{3}{|l|}{ Variables Entered/Removed } \\
\hline Model & $\begin{array}{l}\text { Variables } \\
\text { Entered }\end{array}$ & $\begin{array}{r}\text { Variables } \\
\text { Removed }\end{array}$ & Method \\
\hline 1 & $\begin{array}{l}\text { Kinerja } \\
\text { Komite } \\
\text { Sekolah, } \\
\text { Kepemimpina } \\
\text { n Kepala } \\
\text { Sekolah }\end{array}$ & & Enter \\
\hline
\end{tabular}

a. All requested variables entered.

The table above provides information about the Entered/Removed Variables showing the independent variables in this study as well as the methods used in the regression analysis. The Entered Variables column shows the independent variables in this study, namely School Committee Performance (X1) and Principal Leadership (X2). The regression analysis used is the Enter method. In the Variables Removed column, there are no numbers, this indicates that in this analysis no variables are discarded.

Table 4. Annova

\begin{tabular}{|c|c|c|c|c|c|c|}
\hline \multicolumn{5}{|c|}{ ANOVA } & \multirow[b]{2}{*}{$F$} & \multirow[b]{2}{*}{ Sig. } \\
\hline \multicolumn{2}{|c|}{ Model } & $\begin{array}{l}\text { Sum of } \\
\text { Squares }\end{array}$ & & $\begin{array}{l}\text { Mean } \\
\text { Square }\end{array}$ & & \\
\hline \multirow[t]{3}{*}{1} & Regression & 3626.069 & 2 & 1813.034 & 397.723 & $.000^{\mathrm{a}}$ \\
\hline & Residual & 214.251 & 47 & 4.559 & & \\
\hline & Total & 3840.320 & 49 & & & \\
\hline \multicolumn{7}{|c|}{$\begin{array}{l}\text { a. Predictors: (Constant), Kinerja Komite Sekolah } \\
\text { Kepemimpinan Kepala Sekolah }\end{array}$} \\
\hline \multicolumn{7}{|c|}{ b. Dependent Variable: Mutu Pembelajaran PAI } \\
\hline
\end{tabular}

The Anova table above shows the results of multiple regression analysis, which is indicated by the $F$ value and significance. The decisions on the regression equation are as follows.

If $\mathrm{T}_{\text {count }}>\mathrm{F}_{\text {table }}$ it means that simultaneously there is an effect of independent variables on the dependent variable. In other words $\mathrm{Ho}$ was accepted.

If $\mathrm{T}_{\text {count }}>\mathrm{F}_{\text {table }}$ it means that simultaneously there is no influence of the independent variable on the dependent variable. In other words, Ho was rejected.

Value of Sig. $>0.05$ means that the influence of the independent variable on the dependent variable is significant.

Value of Sig. $<0.05$ means that the effect of the independent variable on the dependent variable is not significant.

Based on the results of multiple regression analysis as in the table above, the $\mathrm{F}$ value is 397.723 with a significance level of 0.000 . In the table the $F$ value with a significance level of 0.05 , with $\mathrm{db}$ 2 and $n 48$, the $F$ value is 3.19. Thus $F_{\text {count }}$ $>F_{\text {table, }}$ meaning that there is an effect of 
the independent variable on the dependent variable. The significance value in the table is $0.000<0.05$. Thus, it means that the performance of the school committee and the leadership of the principal has a significant effect on the quality of Islamic education learning. The magnitude of the simultaneous influence of the independent variables on the dependent variable can be seen in the Model Summary table below.

Table 5. Model Summary

\begin{tabular}{|c|c|c|c|c|}
\hline \multicolumn{5}{|c|}{ Model Summary } \\
\hline Model & $\mathrm{R}$ & \begin{tabular}{|l}
$\mathrm{R}$ \\
Square
\end{tabular} & $\begin{array}{l}\text { Adjusted } \\
\text { R Square }\end{array}$ & $\begin{array}{l}\text { Std. Error } \\
\text { of the } \\
\text { Estimate }\end{array}$ \\
\hline 1 & $.972^{\mathrm{a}}$ & .944 & .942 & 2.135 \\
\hline
\end{tabular}

Based on the Model Summary Table above, information on the value of the coefficient of determination, namely the contribution of the influence of the School Committee Performance (X1) and Principal Leadership (X2) variables simultaneously (together) on the Islamic Education Learning Quality variable (Y).

Based on the Model Summary table above, it is known that the coefficient of determination or $\mathrm{R}$ Square is 0.942 . The $R$ Square value of 0.942 comes from the square of the correlation coefficient $(\mathrm{R})$, which is $0.972 \times 0.972=$ 0.944. Thus, the magnitude of the coefficient of determination ( $\mathrm{R}$ Square) is 0.944 or $94.4 \%$. This figure implies that the School Committee Performance (X1) and Principal Leadership (X2) variables simultaneously affect the quality of Islamic Education Learning (Y) by
$94.4 \%$. The rest $(100 \%-94.4 \%) 3.6 \%$ is influenced by other variables not examined in this study.

To see the regression equation and the magnitude of the influence of each independent variable can be seen in the following Coefficients table.

Table 6. Coefficients

\begin{tabular}{|c|c|c|c|c|c|c|}
\hline \multicolumn{7}{|c|}{ Coefficients $^{\mathrm{a}}$} \\
\hline \multirow{2}{*}{\multicolumn{2}{|c|}{ Model }} & \multicolumn{2}{|c|}{$\begin{array}{l}\text { Unstandardized } \\
\text { Coefficients }\end{array}$} & \multirow{2}{*}{\begin{tabular}{|l}
$\begin{array}{l}\text { Standardized } \\
\text { Coefficients }\end{array}$ \\
Beta
\end{tabular}} & \multirow[b]{2}{*}{$t$} & \multirow[b]{2}{*}{ Sig. } \\
\hline & & B & $\begin{array}{l}\text { Std. } \\
\text { Error }\end{array}$ & & & \\
\hline \multirow[t]{3}{*}{1} & (Constant) & 5.274 & 5.973 & & .883 & .382 \\
\hline & $\begin{array}{l}\text { Schools } \\
\text { committee } \\
\text { performance }\end{array}$ & .378 & .072 & .379 & 5.283 & .000 \\
\hline & $\begin{array}{l}\text { Schools } \\
\text { leadership }\end{array}$ & .664 & .076 & .623 & 8.686 & .000 \\
\hline
\end{tabular}

Based on the coefficients table above, it can be seen that the significance (Sig.) Of the School Committee Performance variable (X1) is 0.000 and the Principal Leadership (X2) is 0.000 . Significance of $0.000<0.05$. Thus it can be concluded that the two independent variables in this study partially (individually) have an effect on the Quality of Islamic Education Learning (Y).

Based on the SPSS output in the table above, it can be seen that the $t_{\text {count }}$ of the School Committee Performance variable $(X 1)$ is 5.283 and the Principal Leadership variable $(\mathrm{X} 2)$ is 8.686. At $t_{\text {count }}$ with dk 47 with a significance level of 0.05 obtained a value of 2.021. $\mathrm{T}_{\text {count }}$ Performance of the School Committee $(\mathrm{X} 1)$ of $5.283(\mathrm{X} 1)>2.021$ (t-table) so that it can be concluded that there is an influence of School Committee Performance $(\mathrm{X} 1)$ on the Quality of e-ISSN: 2715-4572 p-ISSN: 2716-1439 
Islamic Education Learning $(\mathrm{Y})$. $\mathrm{T}_{\text {count }}$ of the Principal Leadership variable $(\mathrm{X} 2)$ of $8.686(\mathrm{X} 2)>2.021$ (t-table) so that it can be concluded that there is an influence of the Principal Leadership variable (X2) on improving the Quality of Islamic Education Learning (Y).

\section{Discussion}

Based on statistical calculations, it can be seen that the School Committee Performance variable (X1) is 0.378 with a significance level of 0.05 on the Quality of Islamic Education Learning (Y). The results of the study found that there was a significant influence between the influence of the school committee's performance on improving the quality of Islamic education learning at Balaesang 8 Elementary School by $37.8 \%$ and the remaining $62.2 \%$ was influenced by other factors outside the research. It means that the higher the influence of the school committee's performance, the higher the increase in the quality of Islamic education learning in Balaesang 8 Elementary School.

This is because the school committee is an institution that is located in each educational unit, and is an independent body that does not have a hierarchical relationship with government institutions that are in the middle between parents, students, teachers, the local community, and the private sector which is formed and play a role in improving the quality of service by providing consideration, direction, support for personnel, infrastructure, and supervision of education at the educational unit level.
In line with Masaong and Ansar's opinion that the School committee is an institution located in each educational unit, and is an independent body that does not have a hierarchical relationship with government institutions that are in the middle between parents, students, teachers, local communities, and other circles. the private sector that is formed and plays a role in improving the quality of services by providing consideration, direction and support for personnel, infrastructure, and educational supervision at the educational unit level. ${ }^{35}$

Furthermore, the results of statistical calculations also show that the principal leadership variable (X2) is 66.4, so it can be said that there is an influence of the principal leadership variable (X2) on improving the quality of Islamic education learning $(Y)$. The results of the study found that there was an influence of the principal's leadership on improving the quality of Islamic education learning at Balaesang 8 Elementary School by $66.4 \%$ and the difference was $33.6 \%$ influenced by other factors outside the research. This means that the higher the influence of the principal's leadership, the higher the increase in the quality of Islamic Education learning at Balaesang 8 Elementary School. This is because the principal is able to influence others and is willing to work together on tasks to achieve the desired goals. The principal has a very big role in developing

35 Masaong dan Ansar. Manajemen Berbasis Sekolah. (Teori, Model, dan Implementasi di Sekolah Dasar. Gorontalo: Nurul Djanah, 2007), 165

e-ISSN: 2715-4572 p-ISSN: 2716-1439 
education, harmonious cooperation, a pleasant working atmosphere and the quality of the principal's leadership.

The principal is one of the components of education that is influential in improving teacher performance. The principal is responsible for carrying out educational activities, school administration, coaching other personnel, and utilizing and maintaining facilities and infrastructure. The principal is not maximal in guiding and guiding teachers, so that there are still teachers who are less disciplined in their duties, arrive late and leave early. conditions like that are the problem in educational institutions. 36

Reksoprodjo Handoko said that leadership is a relationship between a person and another, a leader is able to influence others to be willing to work together in related tasks to achieve the desired goals. ${ }^{37}$ Abi Sujak argues that leadership is a relationship between individuals who use authority and influence on another person or group of people in order to form cooperation to complete a task. ${ }^{38}$

A leader has an important role in improving the quality of education in the educational institution. He leads the leader where they must have the

36 Kasidah, Murniati AR, dan BahrunJurnal Magister Administrasi Pendidikan Pascasarjana Universitas Syiah Kuala. Volume 5, No. 2, 2017) ,

37 Reksoprodjo Handoko, Organisasi Perusahaan Teori Struktur dan Perilaku, (Yogyakarta : BPFE, 1994), h. 66

38 Abi Sujak, Kepemimpinan, Manajer (Eksistensinya dalam Prilaku Organisasi), (Jakarta : Rajawali Pers, 2009), h. 9 requirements so that the leader carries out his assigned duties and responsibilities to work with teachers and staff.

\section{Conclusions}

There is an influence of the school committee's performance on the quality of Islamic education learning. at Balaesang 8 Elementary School. Quality education is the most basic need that is generated through quality education. Education will continue to develop, and always keep abreast of developments in science and technology that are currently developing in society. Establishment of school committees as an effort to involve the community in improving service quality by providing consideration, direction and support for personnel, facilities and infrastructure as well as education supervision at the educational unit level. The principal as the creator of the learning community is a manifestation of the principal's personal competence, which is basically someone who has a passion for learning and is willing to teach all school members in order to improve the performance of the school committee.

There is an influence of the principal's leadership on improving the quality of Islamic education learning at Balaesang 8 Elementary School. The success of education is influenced by the leadership of the principal in improving teacher performance. The principal is one of the components of education that is influential in improving teacher performance. The principal is responsible for carrying out educational activities, school administration, coaching other personnel, and utilizing e-ISSN: 2715-4572 p-ISSN: 2716-1439 
and maintaining facilities and infrastructure. As a leader has an important role in improving the quality of education in the educational institution he leads, the principal has the requirements so that the leader can carry out his duties and responsibilities.

\section{References}

Abi Sujak, Kepemimpinan, Manajer (Eksistensinya dalam Prilaku Organisasi), Jakarta : Rajawali Pers, 2009.

Ali L. Kamus Besar Bahasa Indonesia, Jakarta: Departemen Pendidikan Dan Kebudayaan, 1996.

Asrof Syafi'i, Metodologi Penelitian Pendidikan, Surabaya: eLKAF, 2005.

Abdul Kadir, Dasar-Dasar Pendidikan. Cet. 2; Jakarta: Kencana, 2014.

Abdul Majid, S.Ag, dan Dian Andayani, Pendidikan Agama Islam Berbasis Kompetensi: Konsep dan Implementasi Kurikulum 2004, Cet. 3; Bandung: PT Remaja Rosdakarya, 2006.

Amarin, Sunandar, dan Noor Miyono Https:/ /Www.Researchgate.Net/ Publication/321976513_Peran_Ko mite_Sekolah_Dalam_Manajemen_ Berbasis_Sekolah_Di_SD_Islam_Te rpadu_Buah_Hati_Kabupaten_Pe malang).

Bambang Suteng Sulasmono dan Murjini. Evaluasi Kinerja Komite Sekolah Dalam Peningkatan Mutu Pendidikan.

(File:// /C:/Users/Acer/Downlo ads/Evaluasi_Kinerja_Komite_Se kolah_Dalam_Peningkatan_.Pdf) diakses tanggal 5 Maret 2019
Cholid Narbuko, Ahmadi, Metodologi Penelitian, Jakarta: Bumi Aksara, 2010

Depdiknas. Manajemen peningkatan mutu berbasis sekolah: Konsep dasar. Jakarta: Ditjen Dikdasmen, 2002.

Dirawat et.al, Pengantar Kepemimpinan Pendidikan, Surabaya: Usaha Nasional, 1983.

Depag RI, Al-Qur'an dan Terejemahannya, Surabaya: Cipta Aksara, 1993.

Dirawat Dkk, Pengantar Kepemimpinan

Pendidikan, Surabaya: Usaha Nasiona, 1983.

Dirawat Dkk, Pemimpin Pendidikan Dalam Rangka Pertumbuhan Djabatan Guru-Guru, Malang: Terbitan ke-IV, 1971

Daryanto, Inovasi Pembelajaran Efektif, Bandung: Yrama Widya, 2013.

Evita, E., Syahid, A., \& Nurdin, N. (2019). Understanding Students' Learning Outcomes Differences Through the Application of the Market Place Activity Type of Cooperative Learning Model and the Application of Conventional Learning Models International Journal of Contemporary Islamic Education, 1(1), 67-85.

Kartini Kartono, Pemimpin dan Kepemimpinan, Jakarta: Rajawali Press, 1998.

Kadir, Abdul. 2014. Dasar-Dasar Pendidikan. Cet. 2; Jakarta: Kencana

Kasidah, Murniati AR, dan BahrunJurnal Magister Administrasi Pendidikan Pascasarjana Universitas Syiah Kuala. Volume 5, No. 2, 2017) , Kenneth Leithwood Rosanne Steinbach Doris Jantzi. School Leadership e-ISSN: 2715-4572 p-ISSN: 2716-1439 
and Teachers' Motivation to Implement Accountability Policies. Educational Administration Quarterly Vol. 38, No. 1 (February 2002) 94-119.

Imam Suprayogo, Revormulasi Visi Pendidikan Islam, Malang: Stain Press, cet. I 1999

Majid, Abdul dan Dian Andayani. 2006. Pendidikan Agama Islam Berbasis Kompetensi: Konsep dan Implementasi Kurikulum 2004, Cet.3; Bandung: PT Remaja Rosdakarya.

Miftah Thoha, Kepemimpinan Dalam Manajemen Suatu Pendekatan Prilaku, Jakarta : PT. Grafindo Persada, 1999.

Mulyasa, E. Menjadi Kepala Sekolah Profesional. Bandung: PT Remaja Rosdakarya. TARBAWY, Vol. 3, Nomor 1, 2016.

Masaong dan Ansar. Manajemen Berbasis Sekolah. Teori, Model, dan Implementasi di Sekolah Dasar. Gorontalo: Nurul Djanah, 2007.

Mendiknas,(2007)http://www.puskur.n et/down

load/uu/50Permen_13_2007_Stdr Menteri Pendidikan Nasional No 13 Tahun 2007 Tentang Standar Kepala Sekolah/Madrasah.

Miftah Thoha, Kepemimpinan Dalam Manajemen Suatu Pendekatan Prilaku, Jakarta : PT. Grafindo Persada, 1999.

M. Hidayat Ginanjar, Marfuah As-Surur. Kepemimpinan Kepala Sekolah Dan Pengaruhnya Terhadap Peningkatan Pedagogik Guru Pendidikan Agama Islam Di Smp Negeri 3 Karawang Jawa Barat.. Islamic Management: Jurnal
Manajemen Pendidikan Islam, Vol. I, No. 2, Juli 2018.

Muhaimin, et. al, Paradigma Pendidikan, Bandung: PT Remaja Rosdakarya, 2004.

M. Moh. Rifa'I, Administrasi dan Supervisi Pendidikan, Bandung: Jemmar, 1986

Monica, E.L. Kepemimpinan dan

Manajemen Keperawatan :

Pendekatan berdasarkan

pengalaman. Terjemahan. EGC. Jakarta, 1998.

Ngalim Purwanto, Administrasi dan Supervisi Pendidikan, Bandung: PT. Remaja Rosdakarya, 1991.

Nurdin, N., Pettalongi, S. S., \& Ahsan, M. N. (2019). Implementation of Teaching Quality Assessment System Using Android. 2019 5th International Conference on Science and Technology (ICST)

Nurdin, N. (2018). Institutional Arrangements in E-Government Implementation and Use: A Case Study From Indonesian Local Government. International Journal of Electronic Government Research (IJEGR), 14(2), 44-63. https://doi.org/10.4018/ijegr.201 8040104

Nurdin, N., Stockdale, R., \& Scheepers, H. (2014b, 6-9 Jan. 2014). The Role of Social Actors in the Sustainability of E-Government Implementation and Use: Experience from Indonesian Regencies. System Sciences (HICSS), 2014 47th Hawaii International Conference on System Science

Nurdin, N., Stockdale, R., \& Scheepers, H. (2014a). Coordination and e-ISSN: 2715-4572 p-ISSN: 2716-1439 
Cooperation in E-Government: An Indonesian Local EGovernment Case The Electronic Journal of Information Systems in developing Countries, 61(3), 1-21.

Ojo Karman. Kontribusi kinerja komite sekolah dan kepemimpinan kepala sekolah terhadap peningkatan mutu pembelajaran di sekolah. https://media.neliti.com/media/ publications/75053-ID-

kontribusi-kinerja-komitesekolah-dan-ke.pdf

Panji Anoraga Dkk, Psikologi Industri dan Sosial, Jakarta: Pustaka Jaya, 1995.

Puis.A. Partanto Dan Dahlan Al Barry, Kamus Ilmiah, Surabaya: Arkola, 1994

Priansa, Donni Juni dan Rismi Somad. Manajemen Supervisi dan Kepemimpinan Kepala Sekolah. Bandung : CV Alfabeta, 2014.

Peraturan Menteri Pendidikan Nasional Republik Indonesia. 2013. No 13 Standar Kompetensi Kepala Sekolah. Jakarta : Diknas

Priansa, Donni Juni dan Rismi Somad. Manajemen Supervisi dan Kepemimpinan Kepala Sekolah. Bandung: CV Alfabeta, 2014.

Reksoprodjo Handoko, Organisasi Perusahaan Teori Struktur dan Perilaku, Yogyakarta : BPFE, 1994.

Rosihon Anwar, Akidah Akhlak, Bandung:Pustaka Setia, 2008.

Rivai Veitzai, Manajemen Sumber Daya Manusia untuk Perusahaan, Edisi ke-6, PT Raja Gravindo Persada, 2014.

Rosidah, Sulistiyani, Teguh, Ambar Manajemen Sumber Daya Manusia: Konsep,
Rivai \& Murni, Education Manajemen (Analisis Teori dan Praktik),Jakarta, Rajawali Pers Divisi Buku Perguruan Tinggi PT. Raja Grafindo Persada, 2010.

Robert E. Slavin. Educational

Psychology: Theory and Practice.

Pearson Education. New Jersey, 2000.

Robbins, Stephen P., Perilaku Organisasi: Konsep, Kontroversi dan Aplikasi, Vol. 1. Jakarta: Prenhallindo, 1996.

Reksoprodjo Handoko, Organisasi Perusahaan Teori Struktur dan Perilaku, Yogyakarta : BPFE, 1994.

Rusli, R. (2014c). Teaching Usul al-Fiqh: A Multicultural Education Model. Al-Tahrir: Jurnal Pemikiran Islam, 14(2), 447-464.

Syarifudin, H.E. Manajemen pendidikan. Jakarta: Diadit Media, 2011), 109

Sabri Ahmad, Strategi Belajar Mengajar dan Micro Teaching, (Jakarta: Quantum Teaching, 2005), 51-52.

Sunandar Amarin, dan Noor Miyono, Peran Komite Sekolah Dalam Manajemen Berbasis Sekolah Di SD Islam Terpadu Buah Hati Kabupaten Pemalang.

Suharsimi Arikunto, Prosedur Penelitian, Jakarta: Rineka Cipta, 2010.

Sulistyorini, Hubungan Antara

Manajerial Kepala Sekolah Dan Iklim Organisasi Dengan Kinerja Guru, (Jurnal IlmumPendidikan, Th 28 no.1 Januari 2001.

Sanapiah Faisal, Format-format Penelitian Sosial, Jakarta: Raja Grafindo, 2007.

Sugiyono, Metode Penelitian Pendidikan, Bandung: Alfabeta, 2010. 
Sukardi, Metodologi Penelitian Pendidikan, Jakarta: PT Bumi Aksara, 2008

Sutarto, Dasar-Dasar Kepemimpinan Administrasi, Yogyakarta: Gajah Mada University Press, 1998.

Sulistyorini, Hubungan Antara Manajerial Kepala Sekolah Dan Iklim Organisasi Dengan Kinerja Guru, Jurnal IlmumPendidikan, Th 28 no.1 Januari 2001.

Slameto, Belajar Dan Faktor-Faktor Yang Mempengaruhinya (Jakarta: Rineka Cipta, 2010), 60-64.

Suryosubroto, Proses Belajar Mengajar di Sekolah (Jakarta: Rineka Cipta, 2009), 153-154.

Tanzeh Ahmad, Pengantar Metode Penelitian, Yogyakarta: Teras, 2009.

Teori dan Pengmebangan dalam Konteks Organisasi Publik, Yogyakarta, Graha Ilmu, 2009.

Tim Dosen Admistrasi Pendidikan Universitas Pendidikan Indonesia, Manajemen Pendidikan , ke-8 Bandung: ALFABETA, 2015.

Tilaar, H.A.R. Membenahi Pendidikan Nasional. Jakarta: PT.Rineka Cipta, 2002.

Titik Handayani, Aliyah A Rasyid. Pengaruh Kepemimpinan Kepala Sekolah, Motivasi Guru, Jurnal Akuntabilitas Manajemen Pendidikan Volume 3, No 2, September 2015 (264-277), 266

Toto Fathoni dan Cepi Riyana, "Komponen-Komponen Pembelajaran", dalam Kurikulum dan Pembelajaran dalam Kurikulum dan Pembelajaran, (Jakarta: PT. RajaGrafindo Persada, 2011), 156
Usman, Moch. Uzer. Menjadi Guru Profesional. Bandung: PT Remaja Rosdakarya, 2009.

Undang-Undang Nomor. 20 Tahun 2003. 2013. tentang Sistem Pendidikan Nasional. Sinar Grafika, Jakarta.

Vaitzal Rivai, Memimpin Dalam Abad ke21, Jakarta: PT. Raja Grafindo Persada, 2004.

Wahjosumidjo, Kepemimpinan Kepala Sekolah tinjauan teoritik dan permasalahan. Jakarts: PT. Raja Grafindo Persada, 2002.

Wahjosumidjo, Kepemimpinan Kepala

Sekolah Tujuan Teoritik dan

Permasalahannya. Jakarta :

Rajawali Pers, 2010.

Wina Sanjaya, Kurikulum dan Pembelajaran: Teori dan Praktik Pengembangan Kurikulum Tingkat Satuan pendidikan (KTSP), Jakarta: Kencana, 2010. 